\title{
THE INFLUENCE OF CALCIUM NITRATE ON THE PLASTICIZING EFFECT OF CEMENT PASTE
}

\author{
Gintautas SKRIPKIŪNAS a ${ }^{\mathrm{a}}$ Asta KIČAITÉa ${ }^{\mathrm{a}}$, Mindaugas MACIJAUSKAS ${ }^{\mathrm{a}}$ \\ ${ }^{a}$ Department of Building Materials, Vilnius Gediminas Technical University, \\ Sauletekio al. 11, LT-10223 Vilnius, Lithuania
}

Received 24 Jun 2015; accepted 21 Sep 2015

\begin{abstract}
The rheological properties of the cement pastes have been determined using a rotational viscometer under a special testing routine by increasing and retaining a steady rotation speed of the viscometer cylinder up to certain values and for a certain time. These tests, using rotational viscometer, have been conducted by making the assessment of cement paste flow curves, using Bingham rheological model. Rheological properties of cement pastes were tested at different times after pastes mixing: $0 \mathrm{~min}, 30 \mathrm{~min}, 60 \mathrm{~min}, 90 \mathrm{~min}, 120 \mathrm{~min}$ and $180 \mathrm{~min}$. Cement pastes with same W/C ratio equal to 0.35 were tested. The content of admixture was used $0 \%, 0.5 \%, 1 \%, 2 \%, 3 \%$ and $5 \%$. The admixture of $\mathrm{Ca}\left(\mathrm{NO}_{3}\right)_{2}$ can be used in cement pastes and concretes without a reduction in consistency during 120 min in the dosage of up to $2 \%$. Dosages of $\mathrm{Ca}\left(\mathrm{NO}_{3}\right)_{2}$ from $3 \%$ are not recommended for cement pastes and concrete, they significantly increase the viscosity of mixtures immediately after mixing The admixture of calcium nitrate changes thixotropy of cement pastes. In this case, a bigger dosage of calcium nitrate increases the thixotropy of pastes.
\end{abstract}

Keywords: cement pastes, calcium nitrate, admixture, shear stress, viscosity, thixotropy.

\section{Introduction}

As it is widely known, antifreeze admixures for concrete are chemicals which are added to the mixing water of concrete in order to lower the freezing point of the aqueous solution (Karagöl et al. 2013). That is, however, not the only effect these admixtures might have on the final product.

Antifreeze admixtures can proceed in two different ways: admixtures that lower the temperature of water freezing in the concrete (e.g. $\mathrm{NaNO}_{2}, \mathrm{NaCl}$ and other) and admixtures that not just lower the freezing temperature but also act as a multifunctional admixture in a relatively high temperature (i.e. $20 \pm 2{ }^{\circ} \mathrm{C}$ ) (e.g. potash, $\mathrm{Ca}\left(\mathrm{NO}_{2}\right)_{2}$ and $\left.\mathrm{Ca}\left(\mathrm{NO}_{3}\right)_{2}\right)$. The calcium nitrate can be used for concrete production not only like an antifreeze admixture. It can also be used as an accelerating admixture. The use of accelerators in concrete provides a shortening of setting time and/or an increase in early strength development in the ordinary temperature (Karagöl et al. 2013, 2011; Rixom, Mailvaganam 1999).

Mostly, calcium nitrate is used as a concrete admixture performing various functions, e.g. 1) acceleration; 2) neutralization of plasticizer impact with the same rheological features preserved; 3 ) retaining of long-term strength; 4) anti-frost; 5) corrosion inhibition. In the first two cases, low quantities are used (dry additive content makes up for $0.2-1 \%$ of total cement quantity), in the third and fourth cases, the average quantities are used $(1-3 \%)$, and in the fourth case, higher quantities (3-4\%) (Popovics 1992; Justnes 2007).

Since 1992, technical $\mathrm{Ca}\left(\mathrm{NO}_{3}\right)_{2}$ has been used as a concrete admixture in some countries. It is a complex agent of calcium and ammonium nitrate containing crystal water (Justnes 1993, 2007). It has been found that $\mathrm{Ca}\left(\mathrm{NO}_{3}\right)_{2}$ acted as an accelerator of setting in cement paste at low concentrations (Ramachandra 1972). Because the setting is concerned with the development of rigidity in an initially fluid material, it is assumed to be a part of rheology, the study of flow. Calcium nitrate as a set accelerator, and side effects of that have been well proven practically over many years, while the influence of calcium nitrate on the rheological properties of cement paste was only discovered in later years.

The rheology of the cement paste, mortar and concrete mixture may be influenced by various parameters (Esteves et al. 2010). Rheological features of mixtures are selected according to construction technologies and the equipment used. It is particularly relevant when modern construction technologies are used, e.g. when mixtures are fed by pumps, self-thickening mixtures are produced, etc. 
Cement paste, mortar and concrete mixture are a structural system distinguished by certain rheological features. Cement paste may be considered a flocculant system due to Van der Waals attraction and hydrodynamic impacts (Yahia 2011). Cement pastes are denoted to Bingham bodies (systems), the flow of which is described by two rheological parameters - yield stress $\tau_{0}$ (below which the suspension displays solid-like behaviour) and plastic viscosity $\eta$ (Skripkiūnas et al. 2005; Skripkiūnas, Daukšys 2004; Tang et al. 2001). Plastic viscosity is related to the number and size of the flocs, while the yield stress is a measure of the strength and the number of inter-floc interrelations that are broken down when shear is applied (Puertas et al. 2014; Banfill 2003). The microstructure most commonly responsible for a high yield stress is the three-dimensional network that often forms due to flocculation. The yield stress reflects the extent of this flocculation and the strength of the attractive interparticle forces responsible for the flocculation (Struble, Wei-Guo 1995).

Cement paste is a concentrated suspension of small and heavy particles so rheological measurements are suffering to the disruption of cement operation (Janavičius et al. 2013; Miranda et al. 2010). The rheological properties of the cement paste gradually change with time (Macijauskas, Gailius 2014; Eisinas, Baltakys 2009). Calcium chloride, calcium nitrate and calcium nitrite, which have the same cations as $\mathrm{C}_{3} \mathrm{~S}$ and $\mathrm{C}_{2} \mathrm{~S}$, accelerate the hydration processes by the nucleating action of such ions and simultaneously make hydrate crystallization processes more intensive (Karagöl et al. 2013; Ramachandran 1995). Clearly, the early cement hydration reactions and their associated microstructural changes (i.e. setting) play a major role in controlling the flow behaviour of cement paste. Hydration is known to increase both yield stress and plastic viscosity (Tattersall, Banhill 1983). It presumably increases plastic viscosity only insofar as it increases the volume fraction of the solid material. It is yield stress that is expected to be particularly sensitive to hydration reactions. To the extent that the early hydration products cause the cement particles to be bonded more strongly together or increase the number of inter-particle bonds, hydration is expected to increase the yield stress. Setting corresponds to the development of a substantial yield stress.

Practically, rheological features are useful, whereas they enable forecasting of technological features of a cement paste, mortar, concrete mixture containing corresponding cements with admixtures added or without them,- i.e., the consistency, the possibility to flow, and the possibility to be supplied by pumping.

Numerous methodologies can be used to determine rheological properties of a cement paste. For this purpose, various viscometers could be used, which vary according to the mode of operation (Macijauskas, Gailius 2014; Saak et al. 2001; Ferraris, Gaidis 1992; Yahia, Tanimura 2015; Ng, Justnes 2015). One of the most widespread cement paste rheological characterization techniques is based on the use of a rotational viscometer with coaxial cylinders (Lapasin et al. 1983; Banfill 2003; Nedhi, Rahman 2004).

The purpose of the work is to determine the impact of the dosage of the calcium nitrate (from 0.5 to $5 \%$ ) on rheological properties of the cement pastes (marginal shear tension and viscosity) of a different curing time after mixing from 0 to $150 \mathrm{~min}$.

\section{Raw materials and research methods}

Cement pastes were prepared by mixing in a mixer in accordance with EN 196-1 (2005). Prior to paste mixing, the admixture was dissolved in water. Water with admixture was added to the cement. Mixing was continuing for $120 \mathrm{~s}$ at high speed.

The rheological properties of cement pastes were tested using rotational viscometer with coaxial cylinders Rheotest RN4.1 with a gap of $1.48 \mathrm{~mm}$ between cylinders. The cylinder measuring system consists of the measuring cup (assembled) (1) with a coupling (3) and cylinder rotor (2). The dimensions of testing cylinders are presented in Figure 1.

The cement paste is poured into a measuring cup (1), which is fixed to the equipment stand and immobilised. Inside the measuring cup, the cylinder rotor (2) can rotate. Because of the intrinsic friction of the layers of the cement paste (4) appearing between the measuring cup (1) and the rotating cylinder rotor (2) positioned in the measuring cup and connected to a measuring scale; the cylinder rotor (2) makes a turn and the data displayed on the measuring scale changes.

The shear rates used in the tests are presented in Figure 2.

Rheological properties of cement pastes were tested at different times after paste mixing: $0 \mathrm{~min}, 30 \mathrm{~min}$, $60 \mathrm{~min}, 90 \mathrm{~min}, 120 \mathrm{~min}$ and $180 \mathrm{~min}$. Cement pastes with same $\mathrm{W} / \mathrm{C}$ ratio equal to 0.35 with different

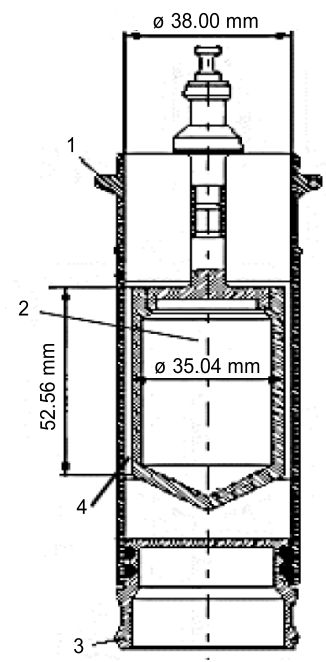

Fig. 1. Principle scheme of testing cylinders 


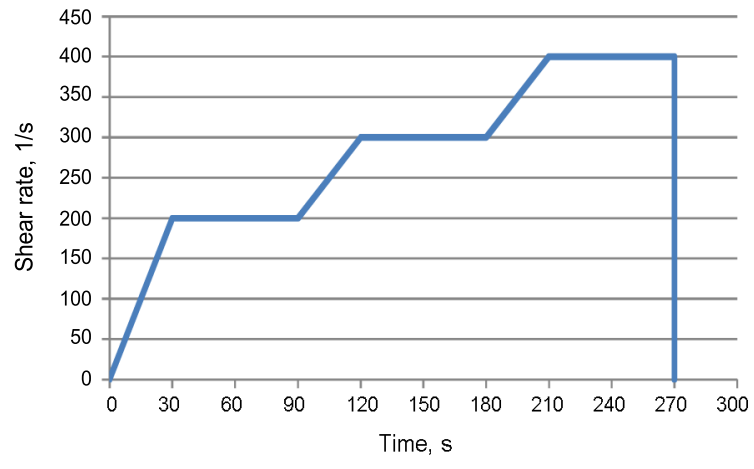

Fig. 2. Shear rates during testing vs testing time

cements were tested. The content of admixture was used $0 \%, 0.5 \%, 1 \%, 2 \%, 3 \%$ and $5 \%$. The tests of rheology were carried out at the temperature of $20 \pm 2{ }^{\circ} \mathrm{C}$.

The yield stress and viscosity of cement pastes were calculated from flow curves ( $\tau$ and $\bar{Y}$ curves) obtained after the test with a rotational viscometer. The flow curves of cement pastes were analysed adopting the Bingham rheological model using the linear approximation of experimental results up to $100-50 \mathrm{~s}^{-1}$ shear rate when the flow curve of cement paste is of linear character. The EXEL computer application was used for this purpose (Fig. 3a). The yield stress of cement pastes $\left(\tau_{0}\right)$ and viscosity $(\eta)$ values were obtained from the linear equation (Bingham rheological model):

$$
\tau=\tau_{0}+\eta \cdot \bar{Y},
$$

where: $\tau$ - shear stress, $\mathrm{Pa} ; \tau_{0}$ - yield stress of cement paste, $\mathrm{Pa} ; \eta$ - viscosity of cement paste, $\mathrm{Pa} \cdot \mathrm{s} ; \overline{\mathrm{Y}}-$ shear rate, $1 / \mathrm{s}$.

The thixotropy of cement pastes was calculated from flow curves of cement pastes obtained after testing at different shear rates (Fig. 3b). The thixotropy value was calculated by the reduction of shear stress during the constant shear rate equal $2001 / \mathrm{s}$ by the equation:

$$
\mathrm{T}=\left(\tau_{1}-\tau_{2}\right) / \tau_{1}
$$

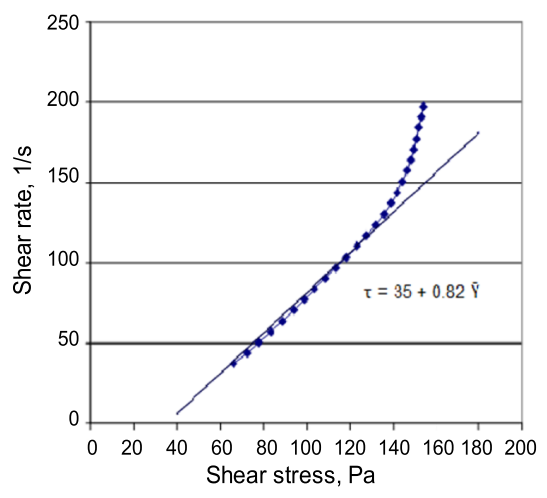

a) where: $\tau_{1}$ is the shear stress at $2001 / \mathrm{s}$ before retention during testing, $\mathrm{Pa}$; and $\tau_{2}$ is the shear stress at $2001 / \mathrm{s}$ after retention during testing, $\mathrm{Pa}$.

For investigations, the following cements (produced in PLLC Akmenes cementas AB) were used: Portland cement CEM I 42,5 R (CEM I R); limestone Portland cement CEM II/A-LL 42,5 N (CEM II N); limestone Portland cement CEM II/A-LL 42,5 R (CEM II R) (Tables 1, 2). Portland cement properties are given in Tables 1 and 2 (data from PLLC Akmenes cementas AB).

Table 1. Properties of cements

\begin{tabular}{l|c|c|c}
\hline Cement type & $\begin{array}{c}\text { Finenessby } \\
\text { blaine, } \\
\mathrm{cm}^{2} / \mathrm{g}\end{array}$ & $\begin{array}{c}\text { Water content } \\
\text { for normal } \\
\text { consistency, \% }\end{array}$ & $\begin{array}{c}\text { Compressive } \\
\text { strength after } \\
\text { 28 days, MPa }\end{array}$ \\
\hline CEM I 42,5 R & 3560 & 25.4 & 54.6 \\
\hline $\begin{array}{l}\text { CEM II/A-LL } \\
42,5 \mathrm{R}\end{array}$ & 4400 & 26.0 & 51.1 \\
\hline $\begin{array}{l}\mathrm{CEM} \mathrm{II/A-LL} \\
42,5 \mathrm{~N}\end{array}$ & 4080 & 25.0 & 51.2 \\
\hline
\end{tabular}

Table 2. Mineral composition of cements

\begin{tabular}{l|c|c|c|c}
\hline \multicolumn{1}{c|}{ Cement type } & $\mathrm{C}_{3} \mathrm{~S}, \%$ & $\mathrm{C}_{2} \mathrm{~S}, \%$ & $\mathrm{C}_{3} \mathrm{~A}, \%$ & $\mathrm{C}_{4} \mathrm{AF}, \%$ \\
\hline CEM I 42,5 R & 64.6 & 7.8 & 6.4 & 12.8 \\
\hline $\begin{array}{l}\text { CEM II/A-LL } \\
\text { 42,5R }\end{array}$ & 58.7 & 12.9 & 6.3 & 10.79 \\
\hline $\begin{array}{l}\text { CEM II/A-LL } \\
42,5 \mathrm{~N}\end{array}$ & 61.8 & 8.57 & 7.1 & 11.9 \\
\hline
\end{tabular}

\section{Experimental results}

\subsection{Flow behaviour of cement pastes}

Cement pastes with different cement type and different $\mathrm{Ca}\left(\mathrm{NO}_{3}\right)_{2}$ admixture content flow curves (shear stress in $\mathrm{Pa}$ vs shear rate in 1/s) are presented in the in Figures 4-9.

Shear stresses of cement pastes with CEM II R cement (the specific surface area of $4400 \mathrm{~cm}^{2} / \mathrm{g}$ ) is higher than that of cement pastes with CEM I R cement (the specific surface area of $3560 \mathrm{~cm}^{2} / \mathrm{g}$ ) and cement pastes with CEM II N cement (the specific surface area of

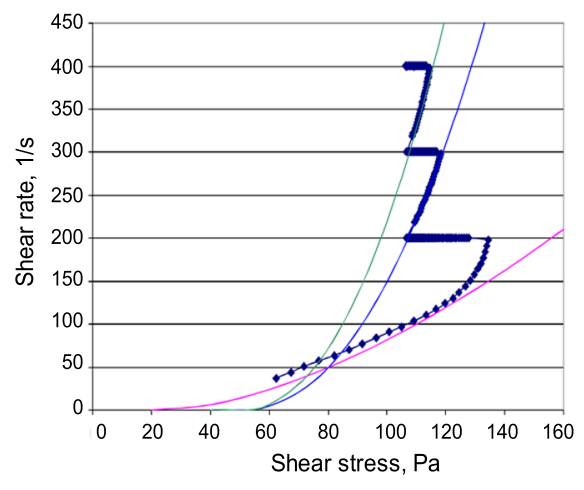

b)

Fig. 3. Calculation of yield stress, viscosity and thixotropy of cement pastes from flow curves 
$4080 \mathrm{~cm}^{2} / \mathrm{g}$ ). In the range of shear rate from 0 to $2001 / \mathrm{s}$, shear stresses are 70-130 Pa, 65-135 Pa and 90-300 Pa for the cements CEM I R, CEM II N and CEM II R, accordingly. The surface area of different types of cements has significant effects on the flowability and rheology of the cement paste. Claisse et al. (2001) have found from their measurement of cement paste rheology and subsequent data analysis that the yield stress of a cement paste would increase with the specific surface area of the cement used and, therefore, having a larger specific surface area would impair the flowability of the cement paste. The fineness of cement has great influence on cement paste shear stresses, i.e. a bigger specific surface of cement gives a bigger shear stress (i.e. the yield point) for cement paste at defined shear rate.

The changes of cement paste shear stress after 120 or 150 min (Figs 5, 7 and 9) are affected by the $\mathrm{Ca}\left(\mathrm{NO}_{3}\right)_{2}$ admixture. It seems that the admixture accelerated the cement hydration. However, the degree of acceleration varied with the dosage of the admixture. In the pastes without admixture with all types of cements, we don't have changes after 120 or $150 \mathrm{~min} . \mathrm{Ca}\left(\mathrm{NO}_{3}\right)_{2}$ admixture content of up to $1 \%$ does not increase the shear stresses after 120 or $150 \mathrm{~min}$ and $0.5 \%$ of admixture usually reduces shear stresses after 120 or $150 \mathrm{~min}$. A bigger content of admixture (from $2 \%$ to $3 \%$ ) significantly increases shear stresses after 120 or 150 min.

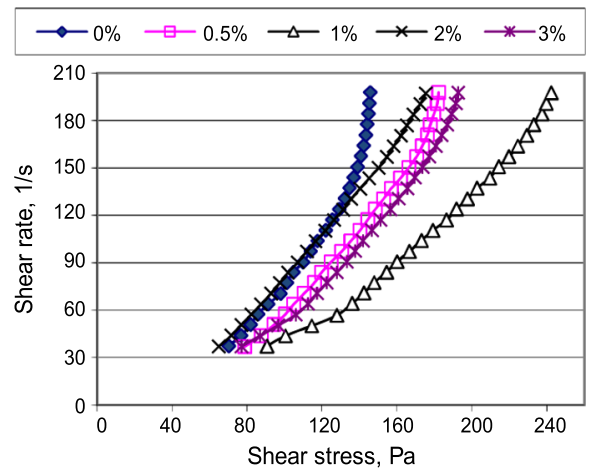

Fig. 4. Cement paste with CEM I R cement shear stress vs shear rate after mixing

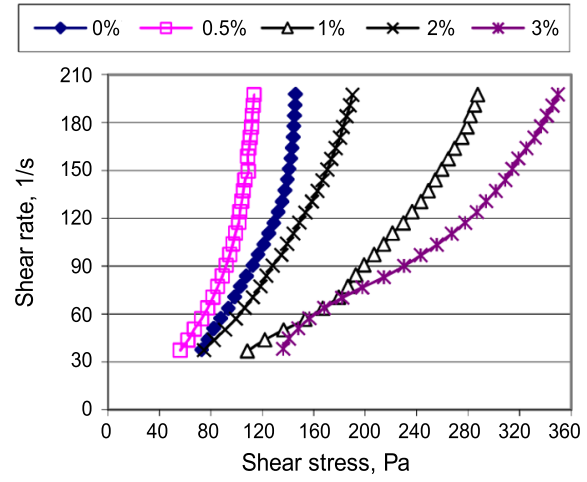

Fig. 5. Cement paste with CEM I R cement shear stress vs shear rate after $120 \mathrm{~min}$

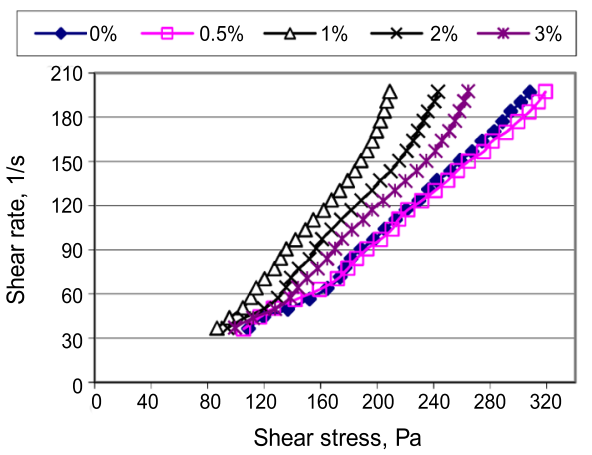

Fig. 6. Cement paste with CEM II R cement shear stress vs shear rate after mixing

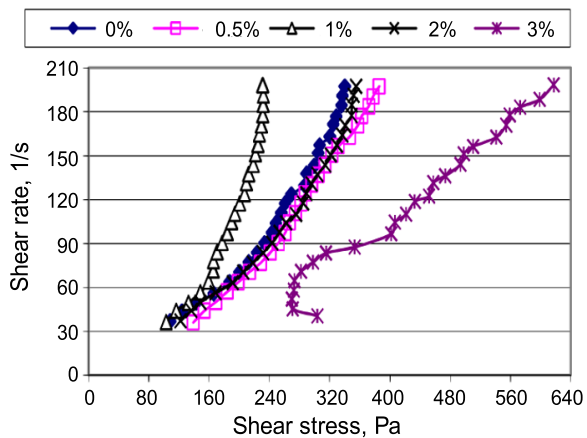

Fig. 7. Cement paste with CEM II R cement shear stress vs shear rate after $150 \mathrm{~min}$

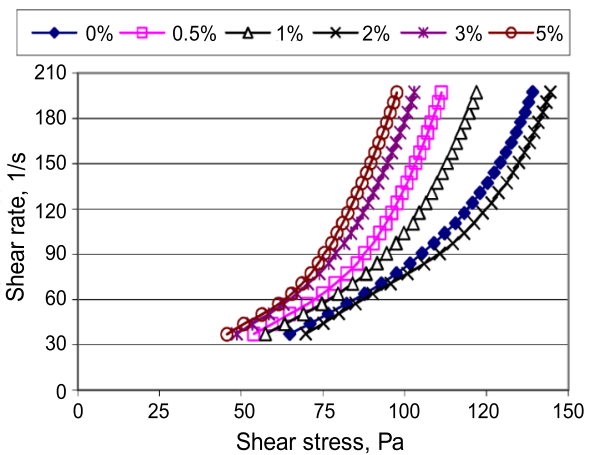

Fig. 8. Cement paste with CEM II N cement shear stress vs shear rate after mixing

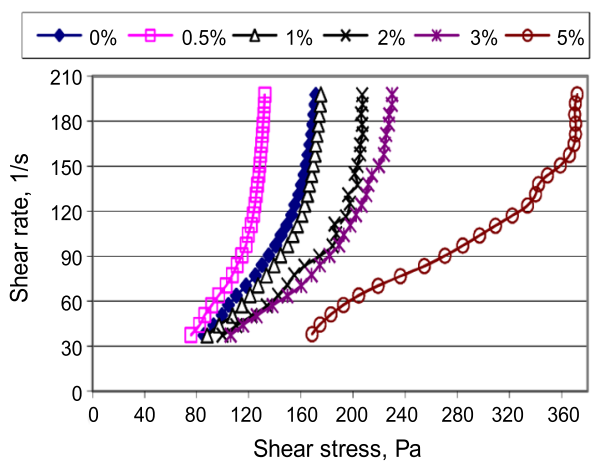

Fig. 9. Cement paste with CEM II N cement shear stress vs shear rate after $150 \mathrm{~min}$ 


\subsection{Yield stresses and viscosities of cement pastes}

The yield stress and viscosity of cement paste were calculated adopting the Bingham rheological model. The yield stress and viscosity results vs time after mixing of cement pastes with a different type of cement are presented in Figures 10-15.

The yield stresses of cement pastes are stable during 120 or $150 \mathrm{~min}$ after mixing in cement pastes without $\mathrm{Ca}\left(\mathrm{NO}_{3}\right)_{2}$ admixture. Only $3 \%$ of this admixture has an influence on the yield stress of the cement paste. The significant increase of yield point of cement paste with $3 \%$ of this admixture starts after 90 min for the cement CEM I R, 60 min for the cement CEM II R and immediately after mixing with $5 \%$ of admixture for the cement CEM II $\mathrm{N}$. Dosages of $\mathrm{Ca}\left(\mathrm{NO}_{3}\right)_{2}$ admixture have no influence on the yield point of the cement paste up to $150 \mathrm{~min}$.

The viscosity of the cement paste after mixing is not higher with $\mathrm{Ca}\left(\mathrm{NO}_{3}\right)_{2}$ admixture content of up to $3 \%$ for the cements CEM I R and CEM II N. For the cement CEM II R (the specific surface of $4400 \mathrm{~cm}^{2} / \mathrm{g}$ ), this admixture has the plasticizing effect. A dosage of admixture from $1 \%$ to $3 \%$ reduces the viscosity of the cement paste immediately after mixing. The admixture of $\mathrm{Ca}\left(\mathrm{NO}_{3}\right)_{2}$ increase the viscosity of the cement paste with the time in dosage more than $2 \%$.

The increment of the viscosity of cement paste with that content of admixture starts after $60 \mathrm{~min}$ in pastes with all cements. A 3\% dosage of this admixture significantly increases the viscosity of the cement paste after 30 min for the cements CEM I R and CEM II N and immediately after mixing for the cement CEM II R. A 5\% dosage of this admixture starts to significantly increase the viscosity of cement paste immediately after mixing.

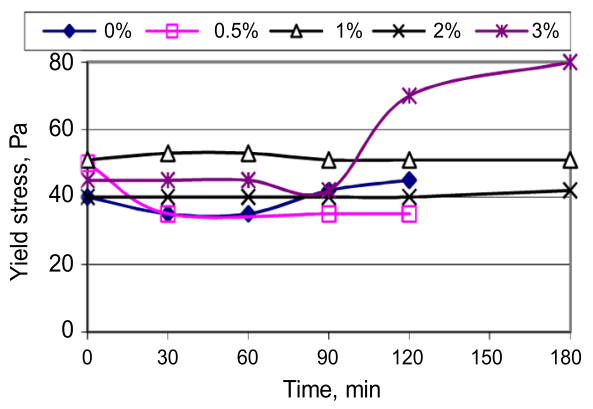

Fig. 10. Cement paste with CEM I R cement yield point

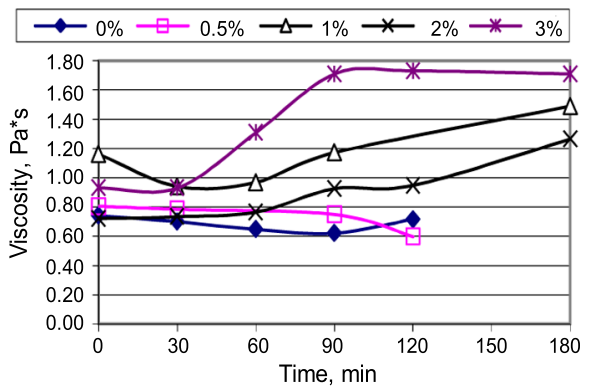

Fig. 11. Cement paste with CEM I R viscosity at shear rate 100 1/s (b) vs time after mixing

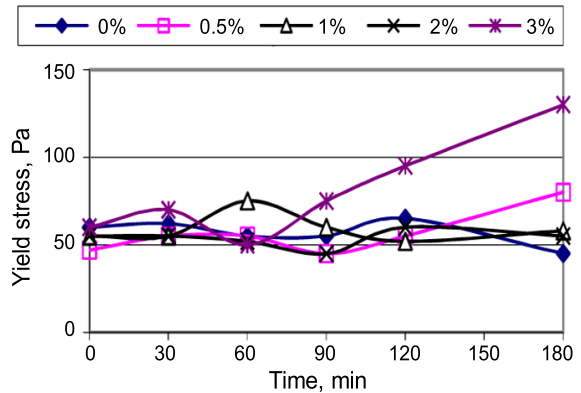

Fig. 12. Cement paste with CEM II R cement yield point

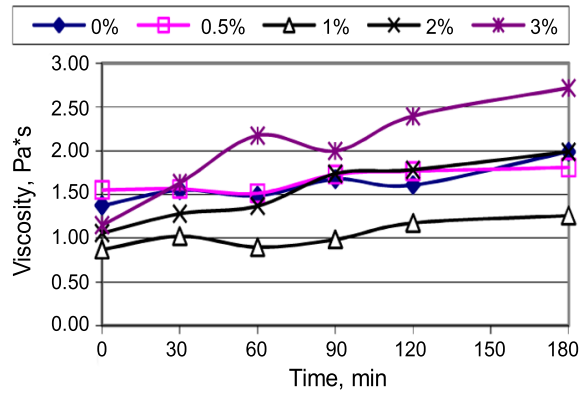

Fig. 13. Cement paste with CEM II R viscosity at shear rate $100 \mathrm{1} / \mathrm{s}$ (b) vs time after mixing

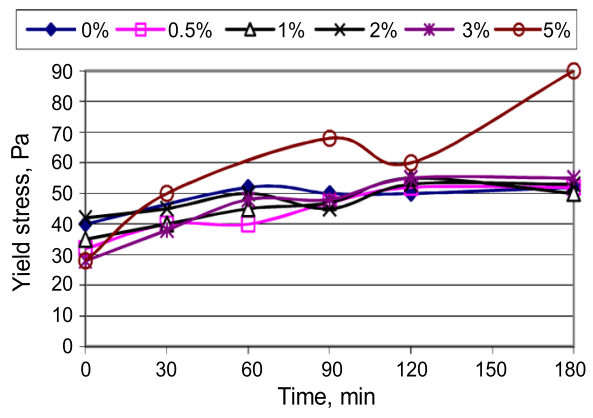

Fig. 14. Cement paste with CEM II N cement yield point

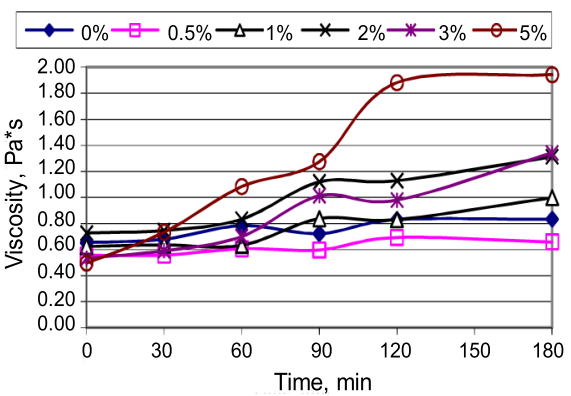

Fig. 15. Cement paste with CEM II N viscosity at shear rate 100 1/s (b) vs time after mixing

Admixture of $\mathrm{Ca}\left(\mathrm{NO}_{3}\right)_{2}$ can be used in cement pastes and concretes without reduction in consistency during $120 \mathrm{~min}$ in the dosage of up to $2 \%$. Dosages from $2 \%$ to $3 \%$ are suitable for mixtures up to $60 \mathrm{~min}$ in time. Dosages of $\mathrm{Ca}\left(\mathrm{NO}_{3}\right)_{2}$ from $3 \%$ are not recommended for cement pastes and concrete, they significantly increase viscosity of mixtures immediately after mixing. 


\subsection{Thixotropy of cement pastes}

Thixotropy is a reversible phenomenon, related to flocculation and deflocculation of the colloidal system under the shear impact load (Roussel et al. 2012). Hence, in case of paste, when sufficient shear is present, under which the paste is capable of returning to its initial state, it is not important whether this process takes place due to flocculation of the colloidal system or due to formed C-S-H links between particles. On the microscopic level, an irreversible reaction takes place during hydration, when links between particles are formed and may be quite weak and broken under shear impact (Jiang et al. 1995; Nonat et al. 1997). During the rest period, additional links form and, if initial links are broken, new links between C-S-H particles appear until there is sufficient place for the formation of new chemical products in the cement system. Formation of chemical linkages in regard to macroscopy may be considered a reversible process, i.e. hydration may be reversible as long as mixing power is sufficient seeking to break C-S-H links between cement particles.

Hydration is the main factor which influences vitality of the mixture, i.e. workability and other technological properties (Flatt, Houst 2001). If the mixture is insufficiently mixed and its internal structure is not fully broken, the mixture has worse workability, other technological properties are also worse (without referring to chemical reactions which take place between chemical admixtures and cement hydration products).

Scientists have examined that the impact of colloidal flocculation of a cement paste on thixotropic properties of the paste is insignificant, and have concluded that formation of C-S-H phases causes the highest impact on thixotropy (Roussel et al. 2012).

This explains why one of the most effective methods for production of highly-thixotropic ready-mixed concrete is the use of admixtures which accelerate the hydration process in the mixture (e.g.: $\mathrm{Ca}\left(\mathrm{NO}_{3}\right)_{2}$ and which are classified as cement accelerators) (Roussel, Cussigh 2008). By mixing the mix using a stirrer of suitable power and by breaking new C-S-H links formed in the paste during the technological process thixotrophic properties of the mixture may be improved without significant reduction of its technological properties (slump of concrete mixture), i.e. preserving the viability of the mixture during the whole technological process.

Thixotropic properties of paste are determined to refer to the change in shear stress within $60 \mathrm{~s}$, when constant speed gradient is $200 \mathrm{l} / \mathrm{s}$.

In the case of a cement paste, it means how long shear is sufficient and the substance returns to its initial state. Even if the chemical reaction is irreversible, when bonds between particles are formed, they may be weak and may be terminated under the shearing impact or new bonds may be spontaneously formed during the rest state as long as the chemical impact reserve is sufficient.

Outcomes of tests of paste's thixotropic properties are presented in the Figures 16-18.

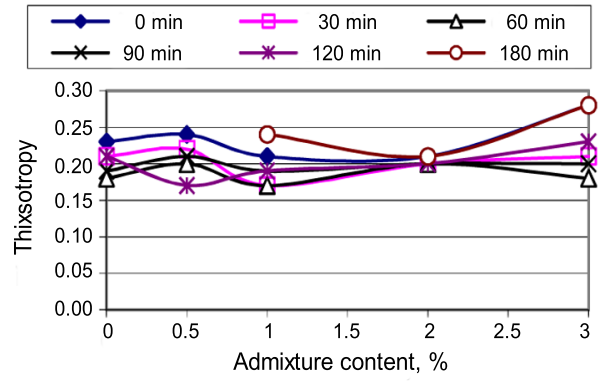

Fig. 16. Thixotropy of cement paste with CEM I R cement

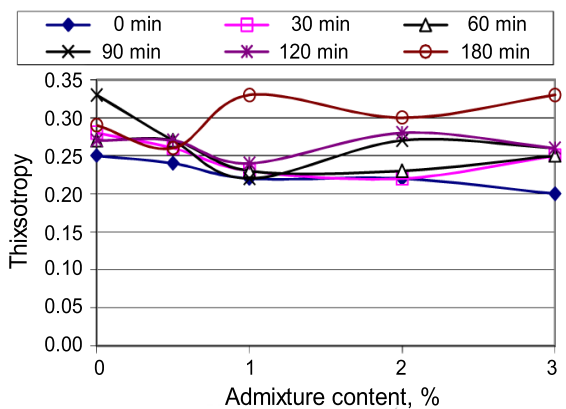

Fig. 17. Thixotropy of cement paste with CEM II R cement

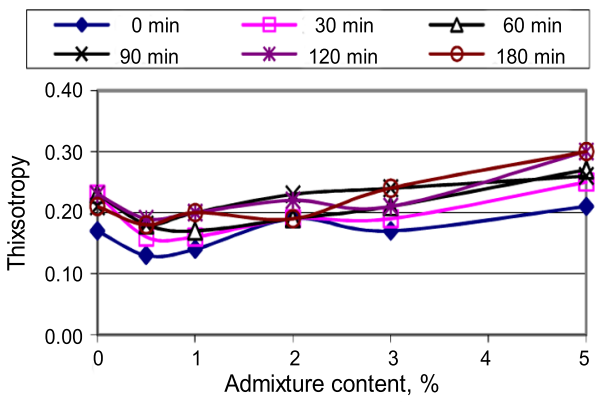

Fig. 18. Thixotropy of cement paste with CEM II N cement

The fineness of cement has a great influence on the cement paste thixotropy. Cement CEM II $\mathrm{R}$ with the specific surface of $4400 \mathrm{~cm}^{2} / \mathrm{g}$ has a higher thixotropy $(0.25-$ 0.33 ) than cements CEM I R and CEM II N with the specific surfaces $3560 \mathrm{~cm}^{2} / \mathrm{g}$ and $4080 \mathrm{~cm}^{2} / \mathrm{g}(0.15-0.20)$.

The admixture $\mathrm{Ca}\left(\mathrm{NO}_{3}\right)_{2}$ does not have the influence on thixotropy of the cement paste up to 120 min after mixing for cements CEM I R and CEM II R. The dosage of admixture $\mathrm{Ca}\left(\mathrm{NO}_{3}\right)_{2}$ of more than $1.0 \%$ increases the thixotropy of the cement paste with cement CEM II N.

\section{Conclusions}

The admixture of calcium nitrate can be used in cement pastes and concretes without a reduction in the consistency during $120 \mathrm{~min}$ in the dosage of up to $2 \%$. Dosages from $2 \%$ to $3 \%$ are suitable for mixtures of up to $60 \mathrm{~min}$ in time. Dosages of calcium nitrate from 3\% are not recommended for cement pastes and concrete as they significantly increase the viscosity of mixtures immediately after mixing. 
The admixture of calcium nitrate changes the thixotropy of cement pastes. In this case, the bigger dosage of calcium nitrate increases the thixotropy of pastes.

The fineness of cement has a great influence on shear stresses and viscosity of cement pastes. The bigger specific surface of cement gives the bigger shear stress (the yield point) and viscosity for cement paste at a defined shear rate. After a longer time after mixing, calcium nitrate reduces the fluidity of the pastes; however, the vibration of these pastes restores the fluidity to the same value as without any admixture of calcium nitrate.

\section{References}

Banfill, P.-F.-G. 2003. The rheology of fresh cement and concrete - a review, in Proc. of $11^{\text {th }}$ International Cement Chemistry Congress, May 2003, Durban, South Africa, $1-13$.

Claisse, P. A.; Lorimer, P.; Omari, M. A. 2001. Workability of cement pastes, ACI Materials Journal 98(6): 476-482.

Eisinas, A.; Baltakys, K. 2009. The possibility of determination of portlandite content in Portland cement was examined by simultaneous thermal analysis, Chemine Technologija 50: $18-23$.

EN 196-1 Methods of testing cement. Determination of strength. European Committee for Standardization, Brussels, 2005. $36 \mathrm{p}$.

Esteves, L. P.; Cachim, P. B.; Ferreira, V. M. 2010. Effect of fine aggregate on the rheology properties of high performance cement-silica systems, Construction and Building Materials 24(5): 640-649.

http://dx.doi.org/10.1016/j.conbuildmat.2009.11.005

Ferraris, C. F.; Gaidis, J.-M. 1992. Connection between the rheology of concrete and rheology of cement paste, $A C I$ Materials Journal 88(4): 388-393.

Flatt, R. J.; Houst, Y. F. 2001. A simplified view on chemical effects perturbing the action of superplasticizers, Cement and Concrete Research 31(8): 1169-1176. http://dx.doi.org/10.1016/S0008-8846(01)00534-8

Janavičius, E.; Daukšys, M.; Skripkiūnas, G.; Nagrockienè, D.; Daugèliene, A. 2013. The effect of cement modification on the rheological properties of cement paste, Journal of Civil Engineering and Management 19(1): 125-130. http://dx.doi.org/10.3846/13923730.2013.851111

Jiang, S. P.; Mutin, J. C.; Nonat, A. 1995. Studies on mechanisms and physico-chemical parameters at the origin of cement setting. 1. The fundamental processes involved during the cement setting, Cement and Concrete Research 25(4): 779-789.

http://dx.doi.org/10.1016/0008-8846(95)00068-N

Justnes, H. 2007. Calcium nitrate as multifunctional concrete admixture, in Slovenian Colloquium on Concrete, 29 May 2007, Ljubljana, Slovenia, 21-28.

Justnes, H. 1993. SINTEF structures and concrete. Report STF70 F93138. Norway, Trondheim. 40 p.

Karagö1, F.; Demirboğa, R.; Kaygusuz, M.-A.; Yadollahi, M. M.; Polat, R. 2013. The influence of calcium nitrate as antifreeze admixture on the compressive strength of concrete exposed to low temperatures, Cold Region Science and Technology 89: 30-35.

http://dx.doi.org/10.1016/j.coldregions.2013.02.001

Karagöl, F.; Demirboğa, R.; Kaygusuz, M.-A.; Yadollahi, M. M. 2011. The influence of calcium nitrate on the compressive strength of concrete exposed to freezing weather, in International Balkans Conference on Challenges of Civil Engineering, BCCCE, 19-21 May 2011, EPOKA University, Tirana, Albania, 1-8.
Lapasin, R.; Papo, A.; Rajgelj, S. 1983. Flow behavior of fresh cement pastes. A comparison of different rheological instruments and technique, Cement and Concrete Research 13(3): 349-356. http://dx.doi.org/10.1016/0008-8846(83)90034-0

Macijauskas, M.; Gailius, A. 2014. Influence of cement type and admixtures on rheological properties of cement pastes, Engineering Structures and Technologies 5(4): 175-181. http://dx.doi.org/10.3846/2029882X.2014.912431

Miranda, C. R.; Petrobas, R. D.; Fairbairn, T. 2010. New design of high-performance cement systems for zonal isolation: influence on porosity, rheological parameters and chemical and mechanical resistance, in Proc. of the SPE Latin American and Caribbean Petroleum Engineering Conference, 1-3 December 2010, Lima, Peru. 12 p.

http://dx.doi.org/10.2118/139307-MS

Nedhi, M.; Rahman, M.-A. 2004. Estimating rheological properties of cement pastes using various rheological models for different test geometry, gap and surface friction, Cement and Concrete Research 34(11): 1993-2007. http://dx.doi.org/10.1016/j.cemconres.2004.02.020

$\mathrm{Ng}$, S.; Justnes, H. 2015. Influence of dispersing agents on the rheology and early heat of hydratation of blended cements with high loading of calcined marl, Cement and Concrete Composites 60: 123-134.

http://dx.doi.org/10.1016/j.cemconcomp.2015.04.007

Nonat, A.; Mutin, J. C.; Lecoq, X.; Jiang, S. P. 1997. Physicochemical parameters determining hydration and particle interactions during the setting of silicate cements, Solid State Ionics 101-103: 923-930. http://dx.doi.org/10.1016/S0167-2738(97)00386-X

Popovics, S. 1992. Concrete materials: properties, specifications and testing. $2^{\text {nd }}$ ed. Noyes: William Andrew Publishing. $661 \mathrm{p}$.

Puertas, F.; Varga, C.; Alonso, M. M. 2014. Rheology of alkali-activated slag pastes. Effect of the nature and concentration of the activating solution, Cement and Concrete Composites 53: 279-288.

http://dx.doi.org/10.1016/j.cemconcomp.2014.07.012

Ramachandran, V. S. 1995. Concrete admixtures handbook. $2^{\text {nd }}$ ed. Cambridge: Cambridge University Press. 1183 p.

Ramachandra, V.-S. 1972. Elucidation of the role of chemical admixtures in hydrating cements by DTA technique, Thermochimica Acta 4: 343-366. http://dx.doi.org/10.1016/0040-6031(72)87017-5

Rixom, R.; Mailvaganam, N. 1999. Chemical admixtures for concrete. $3^{\text {th }}$ ed. E\&FN Spon. 456 p. http://dx.doi.org/10.4324/9780203017241

Roussel, N.; Cussigh, F. 2008. Distinct-layer casting of SCC: the mechanical consequences of thixotropy, Cement and Concrete Research 38(5): 624-632.

http://dx.doi.org/10.1016/j.cemconres.2007.09.023

Roussel, N.; Ovarlez, G.; Garrault, S.; Brumaud, C. 2012.The origins of thixotropy of fresh cement pastes, Cement and Concrete Research 42(1): 148-157. http://dx.doi.org/10.1016/j.cemconres.2011.09.004

Saak, A. W.; Jennings, H. M.; Shah, S.-P. 2001. The influence of wall slip on yield stress and viscoelastic measurements of cement paste, Cement and Concrete Research 31(2): 205212. http://dx.doi.org/10.1016/S0008-8846(00)00440-3

Skripkiūnas, G.; Daukšys, M. 2004. Dilatancy of cement slurries with chemical admixtures, Journal of Civil Engineering and Management 10(3): 227-233. http://dx.doi.org/10.1080/13923730.2004.9636310

Skripkiūnas, G.; Daukšys, M.; Štuopys, A.; Levinskas, R. 2005. The Influence of cement particles shape and concentration on the rheological properties of cement slurry, Materials Science (Medžiagotyra) 11(2): 150-158. 
Struble, L. J.; Wei-Guo, L. 1995. Rheological changes associated with setting of cement paste, Advanced Cement Based Materials 2(6): 224-230. http://dx.doi.org/10.1016/1065-7355(95)90041-1

Tang, C. W.; Yen, T.; Chang, C. S.; Chen, K.-H. 2001. Optimizing mixture propertions for flowable high-performance concrete via rheology tests, ACI Materials Journal 98(6): 493-502.

Tattersall, G. H.; Banfill, P. F. G. 1983. The rheology of fresh concrete. London: Pitman Advanced Publishing Program. $278 \mathrm{p}$.

Gintautas SKRIPKIŪNAS. Prof., Dr, Head of the Department of Building Materials, the Faculty of Civil Engineering, Vilnius Gediminas Technical University (VGTU), Lithuania. Research interests: building materials science, concrete technology, rheological properties of the concrete mixtures, structure and properties of the concrete, durability of concrete, concrete modifications.

Asta KIČAITE். Assoc. Prof. at the Department of Building Materials, the Faculty of Civil Engineering, Vilnius Gediminas Technical University (VGTU), Lithuania. Research interests: building materials science, building materials durability, frost resistance of ceramics, rheological properties of the concrete mixtures, physical and structural properties of building materials.

Mindaugas MACIJAUSKAS. PhD student at the Department of Building Materials, the Faculty of Civil Engineering, Vilnius Gediminas Technical University (VGTU), Lithuania. Research interests: structure and properties of building materials (binders, concrete, dry mixtures), durability, rheological properties, renewable resources in the production of building materials in the context of sustainable development.
Yahia, A. 2011. Shear-thickening behaviour of high-performance cement grouts-influencing mix-design parameters, http://dx.doi.org/10.1016/j.cemconres.2010.11.004

Yahia, A.; Tanimura, M. 2015. Rheology of belite-cementEffect of w/c and high-range water-reducer type, Construction and Building Materials 88: 169-174. http://dx.doi.org/10.1016/j.conbuildmat.2015.03.029 Cement and Concrete Research 41(3): 230-235. 